\title{
Immobilization of heavy metals in sludge using phosphoric acid and monobasic calcium phosphate*
}

\author{
Ping TANG ${ }^{1}$, Yong-chao ZHOU ${ }^{\dagger 2}$, Zhen-miao XIE ${ }^{1}$ \\ ( ${ }^{1}$ College of Environment and Material Engineering, Hangzhou Dianzi University, Hangzhou 310027, China) \\ $\left({ }^{2}\right.$ College of Civil Engineering and Architecture, Zhejiang University, Hangzhou 310027, China) \\ ${ }^{\dagger}$ E-mail: zhoutang@zju.edu.cn
}

Received Oct. 13, 2012; Revision accepted Jan. 16, 2013; Crosschecked Feb. 22, 2013

\begin{abstract}
The purpose of this research is to investigate the potential of pre-treatment with phosphoric acid (PA) and monobasic calcium phosphate (MCP) for the stabilization of heavy metals in sludge and its bottom ash. The tannery sludge samples were collected in Wenzhou, China and heavily contaminated with heavy metals, such as $\mathrm{Pb}, \mathrm{Cr}$ and so on. The samples were pre-treated with PA or MCP. Then XRD and TCLP tests were adopted as the evaluating methods to characterize the $\mathrm{Pb}, \mathrm{Cr}, \mathrm{Cu}, \mathrm{Zn}$ and $\mathrm{Cd}$ immobilization in the pre-treated sludge and its bottom ash. The results showed that this treatment effectively immobilized $\mathrm{Pb}$ and $\mathrm{Cd}$ in the sludge, lightly stabilized the metal $\mathrm{Cu}$, and adversely, enhanced the leachability of $\mathrm{Zn}$. After incineration at $900{ }^{\circ} \mathrm{C}, \mathrm{Pb}$ and $\mathrm{Cr}$ in the bottom ash of pre-treated sludge were significantly stabilized due to the formation of their highly thermostable phosphates and pyromorphite-like minerals during the incineration process. However, an increase of $\mathrm{Cu}$ and $\mathrm{Zn}$ solubility was observed which might be attributable to the acidification of sludge due to the addition of PA or MCP.
\end{abstract}

Key words: Tannery sludge, Bottom ash, Heavy metals, Phosphate, Stabilization doi: 10.1631 jzus.A1200263

Document code: A

CLC number: X705

\section{Introduction}

Treatment of municipal wastewater inevitably leads to the generation of large volumes of sewage sludge. Large quantities of metal elements such as $\mathrm{Cu}$, $\mathrm{Cr}, \mathrm{Pb}$ and $\mathrm{Zn}$, are discharged into sewer system from industrial wastewater; these sources cause sewage sludge to contain heavy metal precipitates (Karvelas et al., 2003). Major disposal and recycling routes for sewage sludge are landfilling, agriculture uses and (co-)incineration. Among these routes, incineration has become the major disposal route due to its large volume reduction, thermal destruction of toxic organic constituents and pathogens, and recovery of

\footnotetext{
Corresponding author

* Project (No. 50908070) supported by the National Nature Science Foundation of China

(C) Zhejiang University and Springer-Verlag Berlin Heidelberg 2013
}

energy (Van de Velden et al., 2008). However, the major problem associated with the thermal treatment of sludge is the possible release of heavy metals to the environment, such as metal volatilization during the process of incineration at high temperature, and metal dissolution through the disposal or recycling of bottom ash and other residuals.

Generally, it has been recognized that the apatite group minerals in nature (which can be expressed by the formula $\mathrm{A}_{5}\left(\mathrm{PO}_{4}\right)_{3}(\mathrm{~F}, \mathrm{Cl}, \mathrm{OH})$, where $\mathrm{A}=\mathrm{Pb}, \mathrm{Zn}, \mathrm{Cd}$, $\mathrm{Cu}$, etc.) are the most thermodynamically stable phosphate species and are relatively insoluble (Piantone et al., 2003). Accordingly, various phosphoruscontaining amendments, such as phosphate rock (Tang et al., 2004; Brown et al., 2005; Cao et al., 2009), phosphoric acid (Cao et al., 2009), hydroxyapatites (Mavropoulos et al., 2002; Raicevic et al., 2009; Mignardi et al., 2012), apatites (Qian et al., 2009; Padmi et al., 2009), and phosphate-based salts 
(Eighmy et al., 1997), have been studied for their roles in the immobilization of heavy metals in soil and incineration residual. For the heavy metal-bearing sludge, phosphorus-containing amendment pretreatment has also been increasingly applied to form apatite structure minerals. Moreover, the process plays an important role in the volatilization abatement of heavy metal during the process of incineration. The high efficiency of vaporization abatement of heavy metals during incineration was pointed out by various studies (Rio et al., 2007; Tang et al., 2008a; 2008b; Sun et al., 2011), and allow us to understand the environmental benefits of incineration.

Incineration of phosphatized sludge leaves more heavy metal compounds in bottom ash because they are not volatilizing during incineration. The concentrations of heavy metals in bottom ash of pre-treated sludge are greater than in the bottom ash of untreated sludge. Considering the reutilization of the bottom ash, its environmental compatibility must also be guaranteed through lowering the leachability of heavy metals. Nevertheless, the knowledge about the influence of pre-treatment with phosphorus-based amendments on stabilization of heavy metals in bottom ash of pre-treated sludge is limited.

The purpose of this study is to evaluate the effectiveness of pre-treatment with phosphorus-based amendments on the immobilization of $\mathrm{Cu}, \mathrm{Zn}, \mathrm{Cr}, \mathrm{Pb}$ and $\mathrm{Cd}$ in tannery sludge and its bottom ash. The specific aims are to compare the effects of phosphoric acid and monobasic calcium phosphate on heavy metal immobilization, and to examine the effectiveness of heavy metal immobilization before and after incineration.

\section{Materials and methods}

\subsection{Materials}

Tannery sludge was collected from Wenzhou, China in 2011. The water contained in the sludge was extracted by mechanical dewatering methods and the moisture content of the samples was decreased to about $75 \%$. The samples were stirred uniformly and then dried at $65^{\circ} \mathrm{C}$. The chemical characteristics and heavy metal concentrations in the sludge were analyzed (Table 1).

Two different phosphorus-based amendments were used to stabilize heavy metals in sludge. One was liquid acid, phosphoric acid (PA), and the other was slightly soluble salt solid, monobasic calcium phosphate (MCP). At room temperature, two groups of tannery sludge, each with six samples, were tested. For each sample, $30.0 \mathrm{~g}$ of material was added to a beaker at room temperature; the water content of each was then adjusted to $50 \%$ to exhibit the rheology of thixotropic slurry, thereby achieving the best compromise between minimum water input and optimal contact between the reactant and the solids (Piantone et al., 2003). The PA $\left(85 \% \mathrm{H}_{3} \mathrm{PO}_{4}\right)$ or MCP powders were doped according to different mass ratios between $\mathrm{PO}_{4}{ }^{3-}$ and dried sludge $(3 \%, 5 \%, 7 \%, 10 \%$, and $20 \%$ ) respectively, and then mixtures were agitated for $5 \mathrm{~h}$ with a magnetic stirrer to ensure thorough mixing before standing for $24 \mathrm{~h}$. Then, the phosphatized sludge was put in a drying bed to avoid moisture interference. Finally, the formed products were utilized for follow-up experiments.

\subsection{Apparatus and experimental procedure}

As shown in Fig. 1, the incineration apparatus used in this study was composed of an electric-heated tube furnace and an air supply. The heart of the furnace was a quartz tube burner, $600-\mathrm{mm}$ long and $40-\mathrm{mm}$ in inner diameter. A porcelain boat moved by quartz rod was designed to feed the sludge into the combustion chamber. The combustion temperature at the center inside of the burner tube was monitored by a thermocouple and controlled by a programmed temperature controller. Finally, the oven was connected to two impingers filled with a solution of $5 \% \mathrm{HNO}_{3}$ allowing for the determination of the collection of the volatilization fraction of the heavy metals.

Table 1 Characteristics of the sludge

\begin{tabular}{cc}
\hline Composition & Value \\
\hline Ultimate analysis (dry basis) $(\%$, in weight) \\
\hline $\mathrm{C}$ & 18.95 \\
$\mathrm{H}$ & 3.12 \\
$\mathrm{O}$ & 16.21 \\
$\mathrm{~N}$ & 2.85 \\
$\mathrm{~S}$ & 0.64 \\
\hline Heavy metal analysis (dry basis) $(\mathrm{mg} / \mathrm{g})$ \\
\hline $\mathrm{Zn}$ & 0.26 \\
$\mathrm{Cr}$ & 17.14 \\
$\mathrm{~Pb}$ & 1.61 \\
$\mathrm{Cd}$ & 0.01 \\
$\mathrm{Cu}$ & 0.03 \\
\hline
\end{tabular}




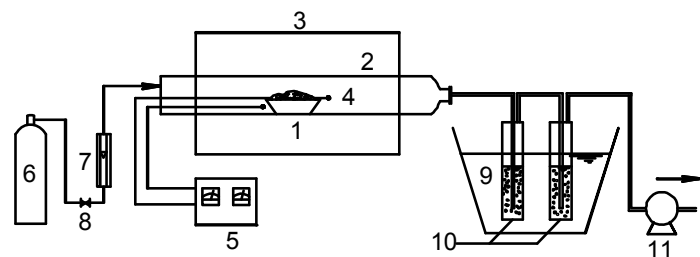

Fig. 1 Laboratory tube furnace for combustion experiment 1: porcelain boat; 2 : quartz tube; 3 : tube furnace; 4: thermocouple; 5: thermocontroller; 6: air supply; 7: flow meter; 8: regulating valve; 9: water cooler; 10 : impingers $\left(5 \% \mathrm{HNO}_{3}\right)$; 11: aspirator pump

Experiments were carried out by the combustion of $10 \mathrm{~g}$ of prepared samples in a porcelain boat that was pushed into a quartz tube. During incineration experiments, air flow rate was fixed at $120 \mathrm{~L} / \mathrm{h}$ and the incineration temperature was $900{ }^{\circ} \mathrm{C}$.

\subsection{Analysis methods}

The leaching test was conducted according to US EPA (1992) SW-846 toxicity characteristics leaching procedure (TCLP) test method 1311 to evaluate the leaching behaviors of $\mathrm{Cu}, \mathrm{Cr}, \mathrm{Pb}, \mathrm{Zn}$ and $\mathrm{Cd}$ in pre-treated sludge and its bottom ash. TCLP is commonly used to determine whether a waste is hazardous and if a treated waste meets the treatment standards for land disposal. This test provides useful information on the potential leachability of metals in sludge and bottom ash. A $5.7-\mathrm{ml}$ aliquot of glacial acetic acid was diluted to $1.0 \mathrm{~L}$ with deionized water. The $\mathrm{pH}$ of the extracting solution was $2.88 \pm 0.05$. The extracting solution was added according to the liquid to solid ratio of $20: 1$.

The mineral phases of samples were identified by X-ray diffraction (XRD) measurement. The XRD analysis was performed on a TD-3500 X-ray diffractometer using MDI Jade 5.0 software (Materials Data Inc., Liverpool, CA). The operating condition of $\mathrm{X}$-ray is $\mathrm{D} / \max -\gamma \beta \mathrm{X}$-ray diffractometer. XRD patterns were obtained from $10^{\circ}$ to $80^{\circ}(2 \theta)$ at a scanning speed of $6 \%$ min.

\section{Results and discussion}

\subsection{Results of leaching heavy metals from pre- treated sludge}

The mobility of metals mobility is strongly associated with their water solubility. Overall, the raw tannery sludge showed higher water solubility of $\mathrm{Pb}$ and $\mathrm{Cr}$. Their concentrations were $0.426 \mathrm{mg} / \mathrm{L}$ and $0.454 \mathrm{mg} / \mathrm{L}$. The high concentrations of soluble $\mathrm{Pb}$ and $\mathrm{Cr}$ were due to the high levels of $\mathrm{Pb}$ and $\mathrm{Cr}$ in the tannery sludge.

The results of the leaching tests are presented in Fig. 2. The results demonstrated that both $\mathrm{PA}$ and MCP used in this study lowered the $\mathrm{Cu}, \mathrm{Pb}$ and $\mathrm{Cd}$ concentrations in the effluent resulting from TCLP experiments. The leachability of $\mathrm{Cu}$ in PA treated tannery sludge decreased from $0.228 \mathrm{mg} / \mathrm{L}$ to 0.181 $\mathrm{mg} / \mathrm{L}$, while it decreased to $0.196 \mathrm{mg} / \mathrm{L}$ when the sludge was pre-treated with MCP as shown in Fig. 2a. The extractable concentrations of $\mathrm{Pb}$ and $\mathrm{Cd}$ in the $\mathrm{PA}$ pre-treated sludge also decreased by about $32.6 \%$ and $44.7 \%$, respectively. In comparison, the extractable concentrations of $\mathrm{Pb}$ and $\mathrm{Cd}$ decreased $26.05 \%$ and $30.3 \%$, respectively, in MCP pre-treated sludge. On the other hand, stability of $\mathrm{Zn}$ was adversely affected from this treatment. Its solubility increased from the initial value of $0.087 \mathrm{mg} / \mathrm{L}$ up to $0.204 \mathrm{mg} / \mathrm{L}$ and $0.192 \mathrm{mg} / \mathrm{L}$ at the highest tested PA and MCP ratios, respectively (Fig. 2b).

For $\mathrm{Cr}$, the leachability was increased greatly from $0.454 \mathrm{mg} / \mathrm{L}$ to $1.736 \mathrm{mg} / \mathrm{L}$ when PA increased from 0 to $5 \%$, and the induction reached a peak when the addition of PA exceeded $7 \%$ as shown in Fig. 2e. Overall, the water solubility of $\mathrm{Cr}$ can be considered nearly unchanged when the sludge was treated with MCP.

\subsection{Results of leaching heavy metals from bottom ash of pretreated sludge}

Figs. 3a-3e shows the leaching results of $\mathrm{Cu}, \mathrm{Zn}$, $\mathrm{Pb}, \mathrm{Cd}$ and $\mathrm{Cr}$ in bottom ash of pre-treated tannery sludge. With incineration, both PA and MCP pretreatments significantly reduced water soluble $\mathrm{Pb}$ and $\mathrm{Cr}$ in the bottom ash. In a comparison between untreated sludge and the $20 \%$ PA pretreated sludge, the $\mathrm{Pb}$ concentration decreased from $0.41 \mathrm{mg} / \mathrm{L}$ to 0.036 $\mathrm{mg} / \mathrm{L}$, while the $\mathrm{Cr}$ decreased from $67.31 \mathrm{mg} / \mathrm{L}$ to $0.098 \mathrm{mg} / \mathrm{L}$. Similarly, the concentrations of $\mathrm{Pb}$ and $\mathrm{Cr}$ resulting from MCP pre-treated sludge also decreased from $0.41 \mathrm{mg} / \mathrm{L}$ to $0.197 \mathrm{mg} / \mathrm{L}$ and from $67.31 \mathrm{mg} / \mathrm{L}$ to $0.261 \mathrm{mg} / \mathrm{L}$, respectively. Fig. 3d shows that treatment of sludge with increasing ratios of PA or MCP resulted in the increased stabilization of $\mathrm{Cd}$ in its bottom ash. PA reduced Cd solubility from 
the initial value of $0.054 \mathrm{mg} / \mathrm{L}$ down to $0.020 \mathrm{mg} / \mathrm{L}$ and $\mathrm{MCP}$ reduced to $0.034 \mathrm{mg} / \mathrm{L}$.

Unlike $\mathrm{Pb}, \mathrm{Cr}$ and $\mathrm{Cd}$, water soluble $\mathrm{Cu}$ and $\mathrm{Zn}$ in bottom ash were elevated after sludge was pre-treated by PA and MCP as shown in Fig. 3a and Fig. $3 b$.

\subsection{Results of XRD analysis}

The XRD patterns of bottom ash of raw tannery sludge incinerated at the temperature of $900{ }^{\circ} \mathrm{C}$, are recorded in Fig. 4. Results showed that the main crystal phases of heavy metals in the bottom ash were $\mathrm{Cr}_{5} \mathrm{O}_{12}, \mathrm{CuO}, \mathrm{Pb}_{11} \mathrm{CrO}_{16}, \mathrm{ZnCr}_{2} \mathrm{O}_{4}$ and $\mathrm{CdCa}$.
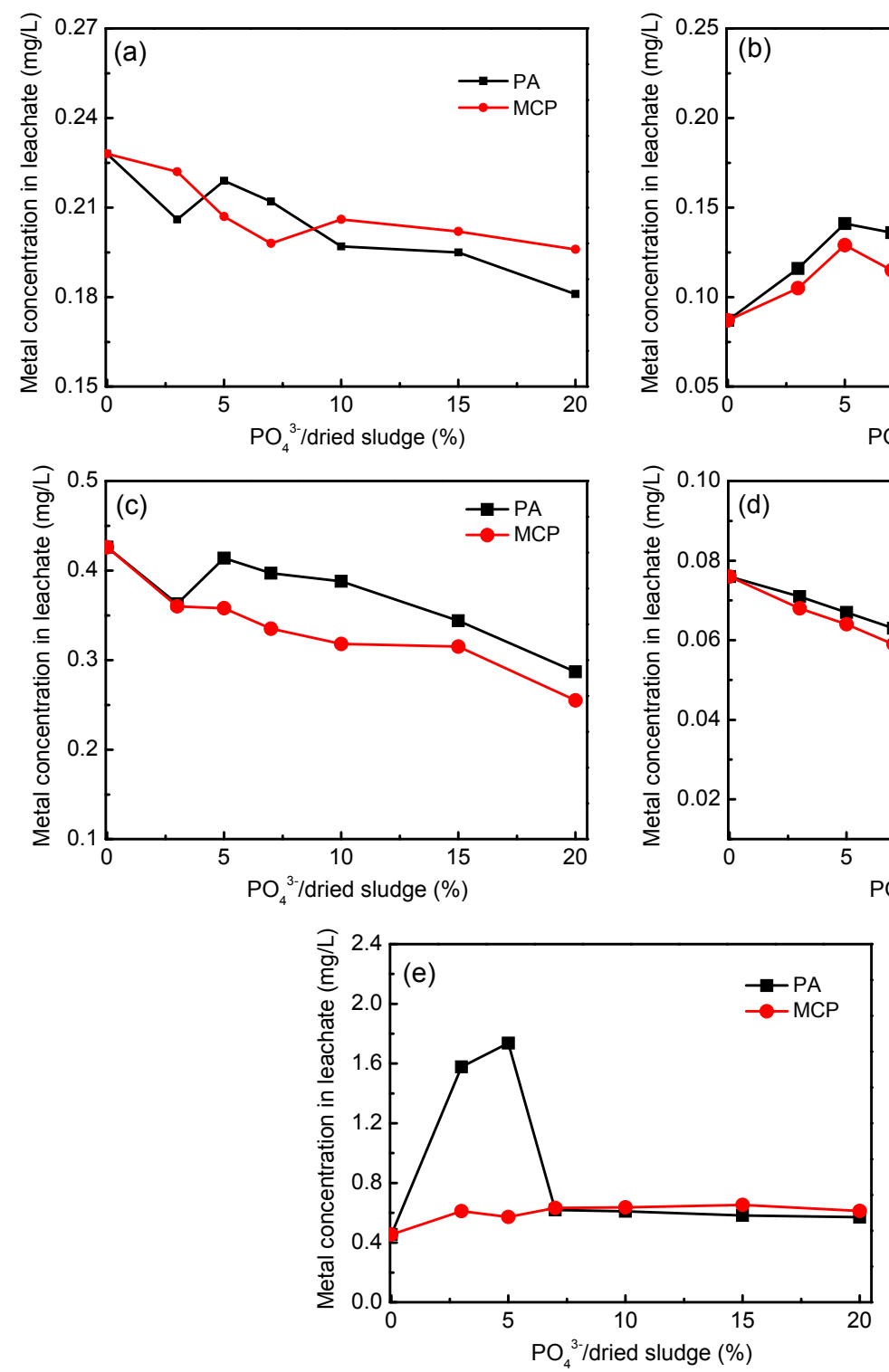

Fig. 2 TCLP concentration of tannery sludge pre-treated by PA and MCP (a) $\mathrm{Cu}$; (b) $\mathrm{Zn}$; (c) $\mathrm{Pb}$; (d) Cd; (e) $\mathrm{Cr}$ with PA.

After sludge was pre-treated with different contents of PA, the XRD patterns of its bottom ash are presented in Fig. 5 (p.182). It was observed that some new mineral compounds, such as $\mathrm{Ca} 9 \mathrm{Cr}\left(\mathrm{PO}_{4}\right)_{7}$, $\mathrm{Pb}_{3} \mathrm{Cr}\left(\mathrm{PO}_{4}\right)_{3}, \quad \mathrm{Zn}_{3}\left(\mathrm{PO}_{4}\right)_{2} 4 \mathrm{H}_{2} \mathrm{O} \quad$ (Hopeite), $\mathrm{Cu}_{3}\left(\mathrm{PO}_{4}\right)(\mathrm{OH})_{3}$ (Libethenite), $\mathrm{Cd}\left(\mathrm{PO}_{3} \mathrm{~F}\right) 2 \mathrm{H}_{2} \mathrm{O}$ and $\mathrm{Pb}_{2} \mathrm{P}_{4} \mathrm{O}_{12} 2 \mathrm{H}_{2} \mathrm{O}$, appeared as shown in Fig. 5. When the content of $\mathrm{H}_{3} \mathrm{PO}_{4}$ increased, the characteristic diffraction peaks near $2 \theta$ of $21^{\circ}, 31^{\circ}, 35^{\circ}$, and $41^{\circ}$ were observed to appear and become obvious. From these peaks, it is almost confirmed that the main formations of heavy metals in bottom ash of sludge doped
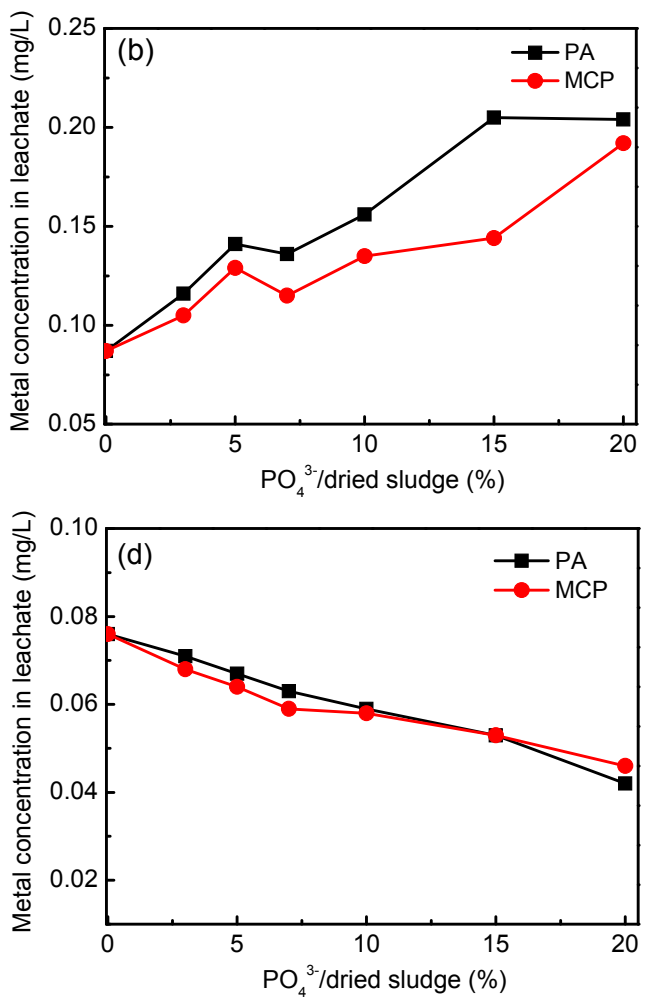

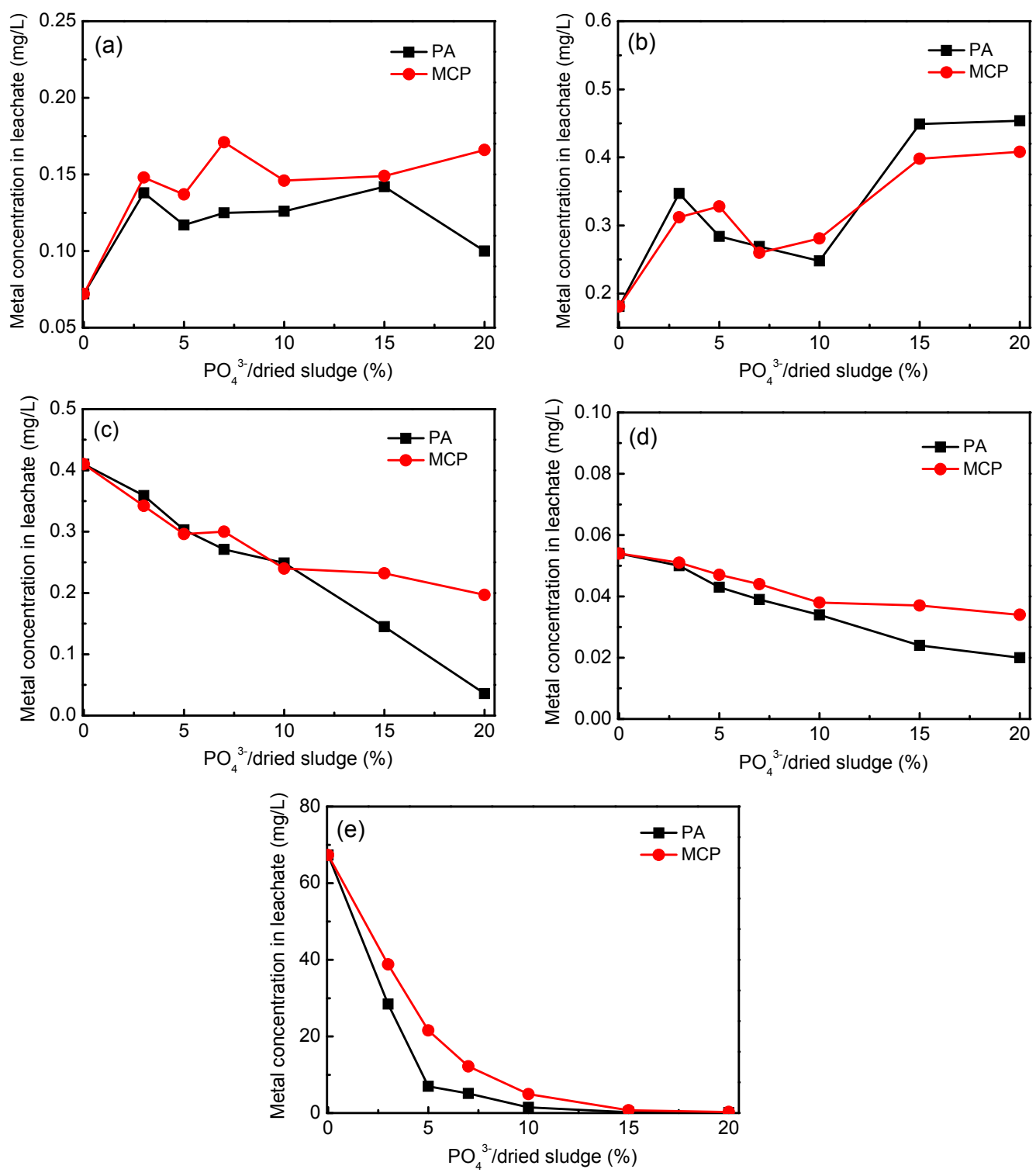

Fig. 3 TCLP concentration of the bottom ash of tannery sludge pre-treated by PA and MCP (a) $\mathrm{Cu}$; (b) $\mathrm{Zn}$; (c) $\mathrm{Pb}$; (d) Cd; (e) $\mathrm{Cr}$

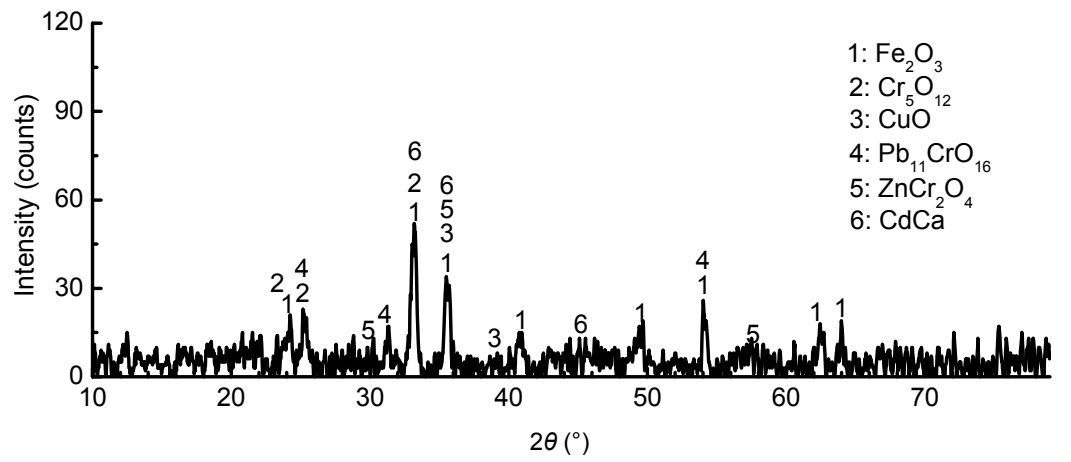

Fig. 4 XRD patterns of bottom ash of raw tannery sludge 
Fig. 6 shows the XRD pattern of the bottom ash of sludge pre-treated with MCP after incineration at $900{ }^{\circ} \mathrm{C}$. The pattern consists of strong intensity peaks corresponding to $\mathrm{Fe}_{2} \mathrm{O}_{3}$ and weak peaks of
$\mathrm{Na}_{3} \mathrm{Cr}\left(\mathrm{PO}_{4}\right)_{2}, \quad \mathrm{~Pb}_{3} \mathrm{Cr}\left(\mathrm{PO}_{4}\right)_{3}, \quad \mathrm{Na}(\mathrm{Fe}, \quad \mathrm{Zn}) \mathrm{PO}_{4}$, $\mathrm{Ca}_{19} \mathrm{Cu}_{2} \mathrm{H}_{2}\left(\mathrm{PO}_{4}\right)_{14}, \quad \mathrm{Cu}_{3}\left(\mathrm{PO}_{4}\right)(\mathrm{OH})_{3}$ (Libethenite), $\mathrm{Cd}\left(\mathrm{H}_{2} \mathrm{PO}_{4}\right)_{2}$ and $\mathrm{Pb}_{3} \mathrm{P}_{4} \mathrm{O}_{13}$. When the content of MCP increased to $20 \%$, the peaks of these minerals also

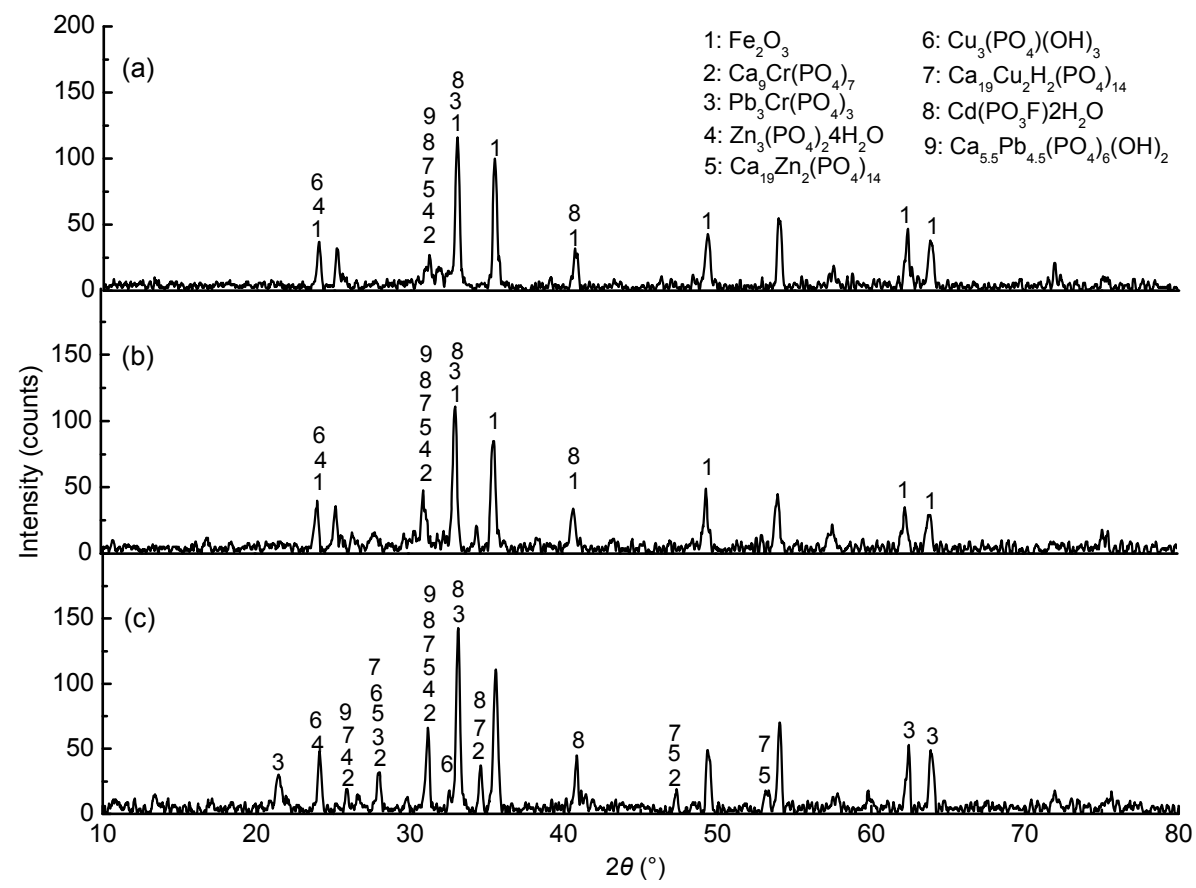

Fig. 5 XRD patterns of bottom ash of tannery sludge pretreated by $5 \%$ (a), $10 \%$ (b), and $20 \%$ (c) PA

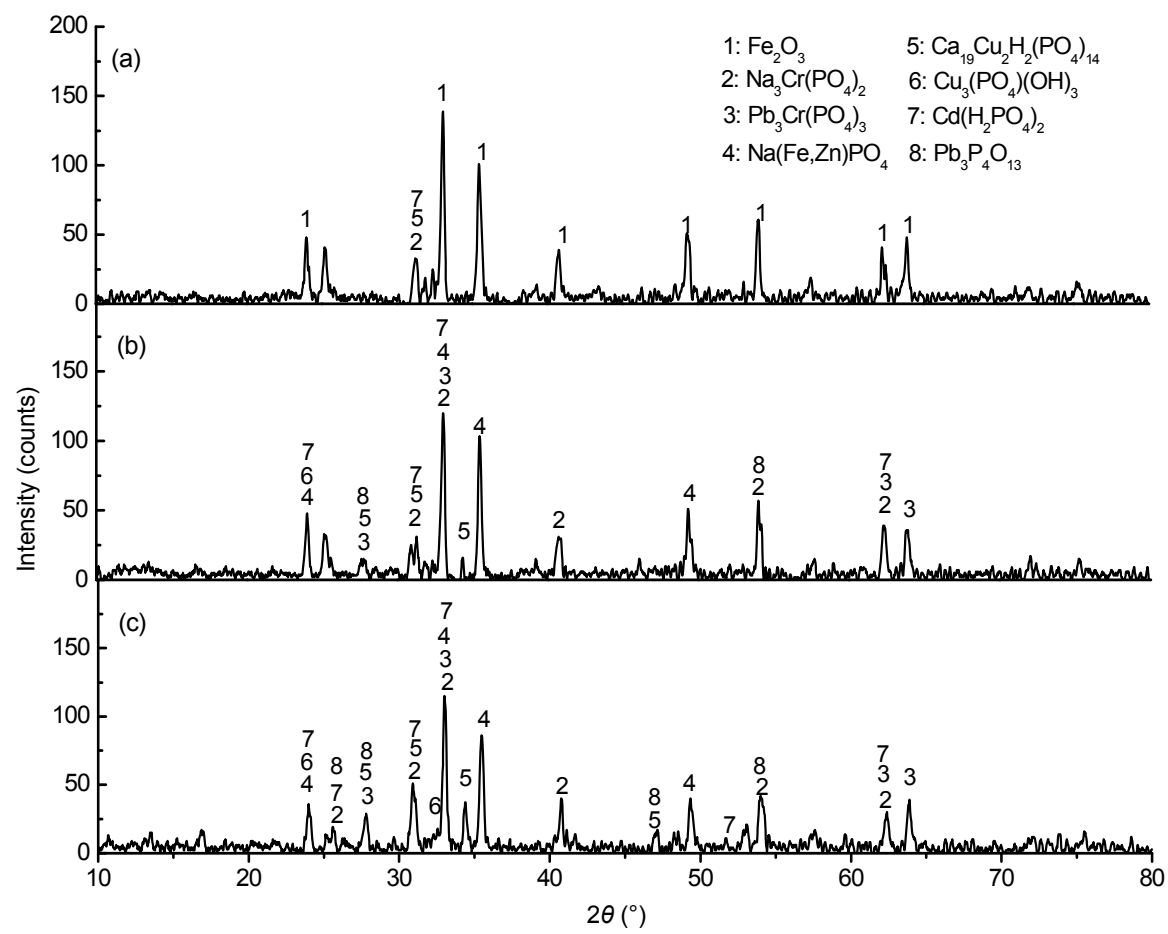

Fig. 6 XRD patterns of bottom ash of tannery sludge pre-treated by $5 \%$ (a), $10 \%$ (b), and $20 \%$ (c) MCP 
became sharper and stronger, indicating that these crystals become the major phase in the bottom ash of sludge pre-treated with MCP.

The mineralogical major phases of the sludge and bottom ash before and after phosphate treatment can be included as shown in Table 2 .

\subsection{Discussion}

When tannery sludge, which may contain $\mathrm{Ca}$ $\mathrm{CO}_{3}$, was mixed with $\mathrm{PA}$, the chemical reaction with $\mathrm{H}_{3} \mathrm{PO}_{4}$ lead to the formation of foam following the reaction

$$
\mathrm{CaCO}_{3}+\mathrm{H}_{3} \mathrm{PO}_{4}+\mathrm{H}_{2} \mathrm{O} \leftrightarrow \mathrm{CaHPO}_{4} \cdot 2 \mathrm{H}_{2} \mathrm{O}+\mathrm{CO}_{2} \uparrow
$$

The foam was formed during the mixing process.

Although most of the PA reacts with $\mathrm{CaCO}_{3}$, the addition of phosphoric acid also allows the formation of other insoluble metal phosphates. As shown in Fig. 2, the reduction of water soluble $\mathrm{Pb}$ in the $\mathrm{PA}$ treatment was attributed to the transformation of $\mathrm{Pb}$ from soluble $\mathrm{Pb}$ to insoluble $\mathrm{Pb}$ phosphate (Table 2). It is thermodynamically favorable for dissolved $\mathrm{Pb}$ to react with $\mathrm{P}$ for formation of insoluble $\mathrm{Pb}$ phosphate, but less for $\mathrm{Zn}$ and $\mathrm{Cu}$ to form $\mathrm{Zn}$ - and $\mathrm{Cu}$-phosphates (Cao et al., 2009), so there are no obvious positive effects for $\mathrm{Cu}, \mathrm{Zn}, \mathrm{Cd}$ and $\mathrm{Cr}$. Moreover, due to the formation of Ca-phosphate in the sludge, $\mathrm{Cu}$ and $\mathrm{Cd}$ can be slightly immobilized due to the ion exchange and complexation mechanisms as shown in Table 2 (Da Rocha et al., 2002).

On the other hand, the exact reaction mechanism responsible for the removal of metal ions by MCP remains unknown. However, previous research suggested that the reaction mechanisms for metal immobilization by phosphate minerals include: (a) ion exchange process; (b) surface complexation; (c) dissolution of the original phosphate minerals and precipitation of new metal phosphates; and, (d) substitution of $\mathrm{Ca}$ in phosphate by other metals during recrystallization (co-precipitation) (Jeanjean et al., 1994; Ma et al., 1994). Several groups suggested that phosphate anions, which can be provided through dissolution of MCP, reacted with lead cations and formed $\mathrm{Pb}_{10}\left(\mathrm{PO}_{4}\right)_{6}(\mathrm{OH})_{2}$ (Ma et al., 1994; $\mathrm{Xu}$ and Schwartz, 1994; Zhang et al., 1997) as

$$
\begin{gathered}
\mathrm{Ca}\left(\mathrm{H}_{2} \mathrm{PO}_{4}\right)_{2} \leftrightarrow \mathrm{Ca}^{2+}+2 \mathrm{H}_{2} \mathrm{PO}_{4}^{-} \\
10 \mathrm{~Pb}^{2+}+6 \mathrm{H}_{2} \mathrm{PO}_{4}^{-}+\mathrm{H}_{2} \mathrm{O} \leftrightarrow \mathrm{Pb}_{10}\left(\mathrm{PO}_{4}\right)_{6}(\mathrm{OH})_{2}+14 \mathrm{H}^{+}
\end{gathered}
$$

Similarly, it also proved that $\mathrm{Cd}$ can be fixed in the formation of Cd-containing phosphates (Mignardi et al., 2012). Therefore, the application of MCP efficiently reduced the extractable fractions of $\mathrm{Pb}$ and $\mathrm{Cd}$ in tannery sludge as shown in Fig. 2. Similar results were also found by Theodoratos et al. (2002) when they stated that the treatment with MCP stabilized $\mathrm{Pb}$ and Cd effectively. Moreover, the fixation mechanism of $\mathrm{Cu}$ and $\mathrm{Zn}$ involved both surface complexation and co-precipitation (Xu and Schwartz, 1994). Ma et al. (1994) also proved that $\mathrm{Cu}$ and $\mathrm{Zn}$ reacted with dissolved $\mathrm{P}$ through precipitation of amorphous to poorly crystalline metal phosphates. Thus, the treatment had slight positive effects for $\mathrm{Cu}$. Contrastingly, addition of PA and MCP to the sludge significantly increased sludge acidity, and the $\mathrm{pH}$ of the suspensions decreased from 10.53 to 4.04 and 5.31, respectively after pre-treatment with PA and MCP. Therefore, a significant increase of $\mathrm{Zn}$ solubility was observed when the PA and MCP doses were increased. Results of this study were consistent with the previous studies

\begin{tabular}{|c|c|}
\hline Sample & Major phase \\
\hline Raw sludge & $\begin{array}{l}\mathrm{CaCO}_{3} ; \mathrm{Cu}_{3}\left(\mathrm{CO}_{3}\right)_{2} \mathrm{OH}_{2} ; \mathrm{Zn}_{5}\left(\mathrm{CO}_{3}\right)_{2}(\mathrm{OH})_{6} ; \mathrm{Ca}_{6} \mathrm{Cr}_{2}\left(\mathrm{SO}_{4}\right)_{3}(\mathrm{OH})_{12} \\
\mathrm{~Pb}_{2} \mathrm{Cu}\left(\mathrm{CrO}_{4}\right)(\mathrm{OH})_{5} ; \mathrm{CdSO}_{4} \mathrm{H}_{2} \mathrm{O}\end{array}$ \\
\hline Bottom ash of raw sludge & $\mathrm{Cr}_{5} \mathrm{O}_{12} ; \mathrm{CuO} ; \mathrm{Pb}_{11} \mathrm{CrO}_{16} ; \mathrm{ZnCr}_{2} \mathrm{O}_{4} ; \mathrm{CdCa}$ \\
\hline $\begin{array}{l}\text { Sludge pretreated with } 20 \% \text { PA } \\
\text { (sludge I) }\end{array}$ & $\begin{array}{l}\mathrm{Pb}_{3}\left(\mathrm{PO}_{4}\right)_{2} ; \mathrm{Pb}_{5}\left(\mathrm{PO}_{4}\right)_{3} \mathrm{OH} ; \mathrm{Cu}_{3}\left(\mathrm{PO}_{4}\right)_{2} ; \mathrm{CaZn}_{2}\left(\mathrm{PO}_{4}\right)_{2} ; \mathrm{CdCrO}_{4} ; \\
(\mathrm{Cu}, \mathrm{Zn})_{3}\left(\mathrm{PO}_{4}\right)(\mathrm{OH})_{3}\end{array}$ \\
\hline Bottom ash of sludge I & $\begin{array}{l}\mathrm{Ca}_{9} \mathrm{Cr}\left(\mathrm{PO}_{4}\right)_{7} ; \mathrm{Pb}_{3} \mathrm{Cr}\left(\mathrm{PO}_{4}\right)_{3} ; \mathrm{Zn}_{3}\left(\mathrm{PO}_{4}\right)_{2} 4 \mathrm{H}_{2} \mathrm{O} ; \mathrm{Cu}_{3}\left(\mathrm{PO}_{4}\right)(\mathrm{OH})_{3} ; \mathrm{Cd}\left(\mathrm{PO}_{3} \mathrm{~F}\right) 2 \mathrm{H}_{2} \mathrm{O} \\
\mathrm{Pb}_{2} \mathrm{P}_{4} \mathrm{O}_{12} \mathrm{H}_{2} \mathrm{O}\end{array}$ \\
\hline $\begin{array}{l}\text { Sludge pre-treated with } 20 \% \mathrm{MCP} \\
\text { (sludge II) }\end{array}$ & $\begin{array}{l}\mathrm{Pb}_{3}\left(\mathrm{PO}_{4}\right)_{2} ; \mathrm{Pb}_{5}\left(\mathrm{PO}_{4}\right)_{3} \mathrm{OH} ; \mathrm{Cu}_{3}\left(\mathrm{PO}_{4}\right)_{2} ; \mathrm{Ca}_{19} \mathrm{Zn}_{2}\left(\mathrm{PO}_{4}\right)_{14} ; \mathrm{Ca} \mathrm{Cr}_{9}\left(\mathrm{PO}_{4}\right)_{7} \\
\mathrm{Ca}_{8} \mathrm{~Pb}_{2}\left(\mathrm{PO}_{4}\right)_{6}(\mathrm{OH})_{2} ; \mathrm{Zn}_{3}\left(\mathrm{PO}_{4}\right)_{2} 4 \mathrm{H}_{2} \mathrm{O}\end{array}$ \\
\hline Bottom ash of sludge II & $\begin{array}{l}\mathrm{Na}_{3} \mathrm{Cr}\left(\mathrm{PO}_{4}\right)_{2} ; \mathrm{Pb}_{3} \mathrm{Cr}\left(\mathrm{PO}_{4}\right)_{3} ; \mathrm{Na}(\mathrm{Fe}, \mathrm{Zn}) \mathrm{PO}_{4} ; \mathrm{Ca}_{19} \mathrm{Cu}_{2} \mathrm{H}_{2}\left(\mathrm{PO}_{4}\right)_{14} ; \mathrm{Cu}_{3}\left(\mathrm{PO}_{4}\right)(\mathrm{OH})_{3} ; \\
\mathrm{Cd}\left(\mathrm{H}_{2} \mathrm{PO}_{4}\right)_{2} ; \mathrm{Pb}_{3} \mathrm{P}_{4} \mathrm{O}_{13}\end{array}$ \\
\hline
\end{tabular}
(Theodoratos et al., 2002; Cao et al., 2009). It can be

Table 2 Major phases of the sludge and bottom ash before and after phosphate treatment 
inferred that the increase of $\mathrm{Zn}$ solubility was attributed to the weak bonds of surface complex mechanism between $\mathrm{Zn}$ and phosphate. This finding also explained why the leachability of $\mathrm{Zn}$ was greater in the bottom ash of PA pre-treated sludge than in the bottom ash of MCP treated sludge as show in Fig. 2b.

With respect to $\mathrm{Cr}$, the initial elevation of $\mathrm{Cr}$ in the case of PA treatment might also be the result of sludge acidification via PA addition. When the PA concentration was further increased, the leachability of $\mathrm{Cr}$ decreased to the level observed without treatment. It could be interpreted that at high levels of PA, the extra PA reacted with $\mathrm{CaCO}_{3}$ which resulted in the reduction of $\mathrm{Cr}$ solubility. However, in agreement with the results of previous study (Quina et al, 2010), the stabilization treatment with PA or MCP does not have a marked positive effect on $\mathrm{Cr}$ stabilization.

After incineration at the temperature of $900{ }^{\circ} \mathrm{C}$, the metal phosphates of heavy metals were stabilized in the bottom ash due to their high thermostability. $\mathrm{Zn}_{3}\left(\mathrm{PO}_{4}\right)_{2} 4 \mathrm{H}_{2} \mathrm{O}$ (Hopeite), $\mathrm{Cu}_{3}\left(\mathrm{PO}_{4}\right)(\mathrm{OH})_{3}$ (Libethenite), $\mathrm{Pb}_{3} \mathrm{P}_{4} \mathrm{O}_{12}, \mathrm{Cd}\left(\mathrm{H}_{2} \mathrm{PO}_{4}\right)_{2}$ were identified in the XRD patterns of bottom ash as major phases (Fig. 5 and Fig. 6). Some of the metal phosphates were apt to bond to each other and form complexes in the combustion process because of the following reaction,

$$
\mathrm{Me}_{3}\left(\mathrm{PO}_{4}\right)_{2}+\mathrm{Ca}_{3}\left(\mathrm{PO}_{4}\right)_{2} \rightarrow \mathrm{Ca}_{n} \mathrm{Me}_{m}\left(\mathrm{PO}_{4}\right)_{k}
$$

Therefore, the minor phases of minerals, such as $\mathrm{Ca}_{19} \mathrm{Zn}_{2}\left(\mathrm{PO}_{4}\right)_{14}$ (Scholzite) and $\mathrm{Ca}_{19} \mathrm{Cu}_{2} \mathrm{H}_{2}\left(\mathrm{PO}_{4}\right)_{14}$, appeared in the bottom ash as shown in Fig. 5 and Fig. 6. Those minerals were more thermally stable and resulted in the accumulation of the heavy metals in the bottom ash during the incineration process (Tang et al., 2008b; Sun et al., 2011). Similarly, addition of PA and MCP can significantly increase bottom ash acidity. Previous research has proved that the solubility of $\mathrm{Cu}$ and $\mathrm{Zn}$ were significantly increased when the $\mathrm{pH}$ decreased within a certain range (Cao et al., 2004). Therefore, sludge pre-treatment with PA and MCP increased $\mathrm{Cu}$ and $\mathrm{Zn}$ solubility in resulting bottom ash as shown in Figs. 3a and 3b.

Lead phosphates, in particular pyromorphite, are the most insoluble forms of $\mathrm{Pb}$ minerals in soils under a wide range of environmental conditions (Lindsay, 1979; Nriagu, 1984). The formation of $\mathrm{Pb}_{3} \mathrm{Cr}\left(\mathrm{PO}_{4}\right)_{3}$ in the combustion also improved the stability of $\mathrm{Pb}$ and $\mathrm{Cr}$ (Fig. 5 and Fig. 6). Hence, the pre-treatments with PA and MCP were seen to efficiently stabilize $\mathrm{Pb}$ and $\mathrm{Cr}$ in the bottom ash of pre-treated sludge. A significant reduction in water soluble $\mathrm{Pb}$ and $\mathrm{Cr}$ in bottom ash of PA and MCP treated sludge was achieved as shown in Figs. 3c and 3e. For Cd, it also showed low leachability in general agreement with the formation of insoluble phases, such as $\mathrm{Cd}\left(\mathrm{PO}_{3} \mathrm{~F}\right)_{2} \mathrm{H}_{2} \mathrm{O}$ and $\mathrm{Cd}\left(\mathrm{H}_{2} \mathrm{PO}_{4}\right)_{2}$. On the other hand, the effectiveness of $\mathrm{PA}$ on the immobilization of $\mathrm{Pb}$, $\mathrm{Cd}$ and $\mathrm{Cr}$ in bottom ash was much better than MCP as shown in Figs. 3c-3e. It may be due to the greater availability of $\mathrm{P}$ in the PA. However, pre-treatment with MCP was similarly effective with respect to PA in immobilizing $\mathrm{Cr}$ in bottom ash. Although less effective, the application of MCP to reduce heavy metal emission from the bottom ash may minimize the potential risk of eutrophication resulting from the use of highly soluble phosphate amendments. Thus, we conclude that MCP is appropriate in the heavy metal immobilization in pre-treatment of tannery sludge that is high in $\mathrm{Cr}$ content before incineration.

\section{Conclusions}

In this study, the pre-treatment of tannery sludge with PA and MCP was tested as a potential heavy metal emission control option. This treatment was shown to effectively stabilize $\mathrm{Pb}$ and $\mathrm{Cd}$ in the tannery sludge. $\mathrm{Pb}$ and $\mathrm{Cd}$ leachability, as determined by TCLP leaching tests, decreased with increasing $\mathrm{P}$ amendment addition rate by $32.6 \%$ and $44.7 \%$ for PA treatment and $40.1 \%$ and $39.5 \%$ for MCP treatment, respectively. $\mathrm{Cu}$ could be slightly immobilized by PA and MCP pre-treatment, falling by $19.6 \%$ and $14.1 \%$, respectively, whereas pre-treatment process had no obvious positive effect for $\mathrm{Cr}$. However, an increase in $\mathrm{Zn}$ leachability was observed, resulting from the acidification of sludge due to the addition of PA or MCP.

After incineration at a temperature of $900{ }^{\circ} \mathrm{C}$, pre-treatment of sludge with phosphorus-containing amendments significantly lowered the water solubility of $\mathrm{Pb}$ and $\mathrm{Cr}$ in the bottom ash. With the increase of $\mathrm{PA}$ or MCP addition, $\mathrm{Pb}$ and $\mathrm{Cr}$ leachability decreased by $91.2 \%$ and $99.8 \%$ for the PA pre-treatment and $52.0 \%$ and $99.6 \%$ for the MCP pre-treatment, 
respectively. Cd could also be effectively stabilized in the bottom ash. The stabilization of these metals was due to the formation of their highly thermostable minerals, such as $\mathrm{Pb}$-phosphates, Cd-phosphates and pyromorphite-like minerals during the incineration process. The results proved that $\mathrm{Pb}, \mathrm{Cr}$ and $\mathrm{Cd}$ in bottom ash had high chemical stability when sludge was pre-treated by phosphorus-containing amendments before incineration. On the other hand, pre-treatment with PA had more effect on heavy metals immobilization than MCP, which may be due to the higher availability of $\mathrm{P}$ in PA. However, the acid extractability of $\mathrm{Cu}$ and $\mathrm{Zn}$ in the bottom ash was increased in the pre-treatment with PA or MCP. This study demonstrates that both $\mathrm{PA}$ and $\mathrm{MCP}$ pre-treatment approaches are suitable for the prevention of heavy metal emission during the incineration of sludge with high $\mathrm{Pb}, \mathrm{Cd}$ and $\mathrm{Cr}$ contents.

\section{References}

Brown, S., Christensen, B., Lombi, E., McLaughlin, M., McGrath, S., Colpaert, J., Vangronsveld, J., 2005. An inter-laboratory study to test the ability of amendments to reduce the availability of $\mathrm{Cd}, \mathrm{Pb}$, and $\mathrm{Zn}$ in situ. Environmental Pollution, 138(1):34-45. [doi:10.1016/j.envpol.2005.02.020]

Cao, X., Ma, L.Q., Rhue, D.R., Appel, C.S., 2004. Mechanisms of lead, copper, and zinc retention by phosphate rock. Environmental Pollution, 131(3):435-444. [doi:10. 1016/j.envpol.2004.03.003]

Cao, X., Wahbi, A., Ma, L., Li, B., Yang, Y., 2009. Immobilization of $\mathrm{Zn}, \mathrm{Cu}$, and $\mathrm{Pb}$ in contaminated soils using phosphate rock and phosphoric acid. Journal of Hazardous Materials, 164(2-3):555-564. [doi:10.1016/j. jhazmat.2008.08.034]

Da Rocha, N.C.C., Decampos, R.C., Rossi, A.M., Moreira, E.L., Barbosa, A.F., Moure, G.T., 2002. Cadmium uptake by hydroxyapatite synthesized in different conditions and submitted to thermal treatment. Environmental Science \& Technology, 36(7):1630-1635. [doi:10.1021/es0155940]

Eighmy, T.T., Crannell, B.S., Butler, L.G., Cartledge, F.K., Emery, E.F., Oblas, D., Krzanowski, J.E., Eudsen, J.D., Shaw, E.L., Francus, C.A., 1997. Heavy metal stabilization in municipal solid waste combustion dry scrubber residue using soluble phosphate. Environmental Science and Technology, 31(11):3330-3338. [doi:10.1021/ es970407c]

Jeanjean, J., Vincent, U., Fedoroff, M., 1994. Structural modification of calcium hydroxyapatite induced by sorption of cadmium ions. Journal of Solid State Chemistry, 108(1): 68-72. [doi:10.1006/jssc.1994.1010]

Karvelas, M., Katsoyiannis, A., Samara, C., 2003. Occurrence and fate of heavy metals in the waste water treatment process. Chemosphere, 53(10):1201-1210. [doi:10.1016/
S0045-6535(03)00591-5]

Lindsay, W.L., 1979. Chemical Equilibria in Soils. John Wiley \& Sons Inc., New York, p.329-342.

Ma, Q.Y., Traina, S.J., Logan, T.J., Ryan, J.A., 1994. Effects of aqueous $\mathrm{Al}, \mathrm{Cd}, \mathrm{Cu}, \mathrm{Fe}(\mathrm{II}), \mathrm{Ni}$, and $\mathrm{Zn}$ on $\mathrm{Pb}$ immobilization by hydroxyapatite. Environmental Science and Technology, 28(7):1219-1228. [doi:10.1021/ es00056a007]

Mavropoulos, E., Rossi, A.M., Costa, A.M., Perez, C.A.C., Moreira, J.C., 2002. Studies on the mechanisms of lead immobilization by hydroxyapatite. Environmental Science \& Technology, 36(7):1625-1629. [doi:10.1021/ es0155938]

Mignardi, S., Corami, A., Ferrini, V., 2012. Evaluation of the effectiveness of phosphate treatment for the remediation of mine waste soils contaminated with $\mathrm{Cd}, \mathrm{Cu}, \mathrm{Pb}$, and Zn. Chemosphere, 86(4):354-360. [doi:10.1016/j. chemosphere.2011.09.050]

Nriagu, J.O., 1984. Formation and Stability of Base Metal Phosphates in Soils and Sediment. In: Moor, P.B. (Ed.), Phosphate Minerals, Springer-Verlag, London, p.318329.

Padmi, S.T., Tanaka, M., Aoyama, I. 2009. Chemical stabilization of medical waste fly ash using chelating agent and phosphates: Heavy metals and ecotoxicity evaluation. Waste Management, 29(7):2065-2070. [doi:10.1016/j. wasman.2009.03.005]

Piantone, P., Bodénan, F., Derie, R., Depelsenaire, G., 2003. Monitoring the stabilization of municipal solid waste incineration fly ash by phosphation: mineralogical and balance approach. Waste Management, 23(3):225-243. [doi:10.1016/S0956-053X(01)00058-7]

Qian, G., Chen, W., Lim, T.T., Chui, P., 2009. In-situ stabilization of $\mathrm{Pb}, \mathrm{Zn}, \mathrm{Cu}, \mathrm{Cd}$ and $\mathrm{Ni}$ in the multi-contaminated sediments with ferrihydrite and apatite composite additives. Journal of Hazardous Materials, 170(2-3):10931100. [doi:10.1016/j.jhazmat.2009.05.093]

Quina, M.J., Bordado, João, C.M., Quinta-Ferreira, R.M., 2010. Chemical stabilization of air pollution control residues from municipal solid waste incineration. Journal of Hazardous Materials, 179(1-3):382-392. [doi:10. 1016/j.jhazmat.2010.03.016]

Raicevic, S., Perovic, V., Zouboulis, A.I., 2009. Theoretical assessment of phosphate amendments for stabilization of $(\mathrm{Pb}+\mathrm{Zn})$ in polluted soil. Waste Management, 29(5):17791784. [doi:10.1016/j.wasman.2008.11.021]

Rio, S., Verwilghen, C., Ramaroson, J., Nzihou, A., Sharrock, P., 2007. Heavy metal vaporization and abatement during thermal treatment of modified wastes. Journal of Hazardous Materials, 148(3):521-528. [doi:10.1016/j. jhazmat.2007.03.009]

Sun, Y., Zheng, J., Zou, L., Liu, Q., Zhu, P., Qian, G., 2011. Reducing volatilization of heavy metals in phosphatepretreated municipal solid waste incineration fly ash by forming pyromorphite-like minerals. Waste Management, 31(2):325-330. [doi:10.1016/j.wasman.2010.10.011]

Tang, X.Y., Zhu, Y.G., Chen, S.B., Tang, L.L., Chen, X.P., 2004. Assessment of the effectiveness of different 
fertilizers to remediate $\mathrm{Pb}$-contaminated soil using in vitro test. Environment International, 30(4):531-537. [doi:10.1016/j.envint.2003.10.008]

Tang, P., Zhao, Y.C., Chen, D.Z., Xia, F.Y., 2008a. Volatility of heavy metals during incineration of tannery sludge in the presence of chlorides and phosphoric acid. Waste Management \& Research, 26(4):369-376. [doi:10.1177/ 0734242X08092024]

Tang, P., Zhao, Y.C., Xia, F.Y., 2008b. Thermal behaviors and heavy metal vaporization of phosphatized tannery sludge in incineration process. Journal of Environmental Sciences, 20(9):1146-1152. [doi:10.1016/S1001-0742(08) 62162-2]

Theodoratos, P., Papassiopi, N., Xenidis, A., 2002. Evaluation of monobasic calcium phosphate for the immobilization of heavy metals in contaminated soils from Lavrion. Journal of Hazardous Materials, 94(2):135-146.
[doi:10.1016/S0304-3894(02)00061-4]

US EPA, 1992. Toxicity Characteristic Leaching Procedure (Method 1311) in SW-846. Office of Solid Waste, Washington DC.

Van de Velden, M., Dewil, R., Baeyens, J., Josson, L., Lanssens, P., 2008. The distribution of heavy metals during fluidized bed combustion of sludge (FBSC). Journal of Hazardous Materials, 151(1):96-102. [doi:10.1016/j. jhazmat.2007.05.056]

Xu, Y., Schwartz, F.W., 1994. Lead immobilization by hydroxyapatite in aqueous solutions. Journal of Contaminant Hydrology, 15(3):187-206. [doi:10.1016/01697722(94)90024-8]

Zhang, P., Ryan, J.A., Bryndzia, L.T., 1997. Pyromorphite formation from goethite adsorbed lead. Environmental Science and Technology, 31(9):2673-2678. [doi:10.1021/ es970087x] 